\title{
ZARZĄDZANIE ZASOBAMI WODNYMI - WYZWANIE NIE TYLKO DLA EKONOMISTÓW
}

\section{WSTĘP}

O podjęciu problematyki zarządzania zasobami wodnymi w nakreślonym niżej kształcie zadecydowało przeświadczenie autorów o potrzebie zintensyfikowania interdyscyplinarnej debaty dotyczącej rozstrzygania dylematów związanych z alokacją tych zasobów, a w konsekwencji usprawnienia systemu dostarczania i wykorzystywania wody.

Wprawdzie wszędzie tam, gdzie zasoby środowiska są wykorzystywane wspólnie, pojawia się ryzyko nadmiernej ich eksploatacji lub całkowitego zużycia ${ }^{1}$, jednak w przypadku zasobów wodnych, dość długo uznawanych za dobra wolne, niewyczerpywalne, funkcjonujace poza rachunkiem ekonomicznym - umiejętne zarządzanie nimi jest obecnie szczególnie ważne. Przy rosnących w skali globalnej barierach dostępu do nich, niemożności wykluczenia użytkowników oraz ich rywalizacyjnej konsumpcji, nie bez powodu określane sa zagrożonym dobrem wspólnym² ${ }^{2}$. Choć podmioty gry gospodarczej (konsumenci, operatorzy, gminy, państwa) działaja dla dobra wspólnego, to jednak ze względu na różne ich cele, czasem przeciwstawne, wynikające $\mathrm{z}$ innych przesłanek decyzyjnych, czynią to dla dobra innej wspólnoty, w innym układzie terytorialnym i w innym horyzoncie czasowym ${ }^{3}$.

Warto dodać, że właśnie dobro wspólne, jedna z najstarszych kategorii o interdyscyplinarnym charakterze, pojawia się obecnie niemal wszędzie tam, gdzie trwa debata nad przyszłościa ekonomiczną świata, nad receptami na kumulujące się problemy gospodarki, polityki i moralności, nad systemowymi oraz instytucjonalnymi warunkami harmonizowania procesów rozwojowych i przezwyciężania czynników dezintegrujących ${ }^{4}$.

1 M. Decko, P. Bielecka, Dynamika systemów jako narzędzie przeciwdziałania tragedii dóbr wspólnych, „Ekonomia i Środowisko” 2015, nr 2(53), s. 11.

${ }_{2}$ Woda-zagrożone dobro wspólne, wywiad z Satoko Kishimoto, koordynatorka projektu dotyczącego sprawiedliwości w dostępie do wody w Transnational Institute (TNI), https://kampanierzy.pl [dostęp: 12.09.2016].

${ }^{3}$ P. Gruszczyński, Etyczne dylematy gospodarki wodno-ściekowej w Polsce, „Annales. Etyka w Życiu Gospodarczym” 2007, nr 1, s. 369.

${ }^{4}$ M. Słodowa-Hełpa, Odkrywanie na nowo dobra wspólnego, „Nierówności Społeczne a Wzrost Gospodarczy” 2015, nr 43(3), s. 8-20. 
W Traktacie ustanawiajacym Wspólnotę Europejską zapewnienie dostępu każdego mieszkańca do dóbr podstawowych, w tym do wody, stanowi jeden z celów usług użyteczności publicznej ${ }^{5}$. Konieczność ochrony zasobów wodnych oraz ich wykorzystywania w myśl zasady zrównoważonego rozwoju wyeksponowana została w preambule dyrektywy ustanawiającej ramy wspólnotowego działania w dziedzinie polityki wodnej, dotyczacej zaspokojenia zapotrzebowania na wodę ludności i gospodarki, poprawy jej jakości i zmniejszenia zanieczyszczeń. Określono tam, że woda nie jest produktem handlowym, takim jak inne, lecz dziedzictwem, które powinno być chronione ${ }^{6}$.

Te okoliczności - w powiązaniu z ewolucją części wcześniejszych poglądów i z propozycją rozwiązań kompromisowych, znajdujących swoje odzwierciedlenie w coraz bardziej rozpowszechnianej ekonomii zrównoważonego rozwoju, ekonomii dobra wspólnego, w etyce antropocentrycznej i ekologicznej ${ }^{7}$ - powinny być uwzględnione w praktyce zarządzania zasobami wodnymi, zarówno w skali poszczególnych krajów, regionów, wspólnot lokalnych, jak i w wymiarze globalnym. Nie tylko ekonomiści, lecz i badacze innych dyscyplin, politycy, praktycy gospodarczy, a także wspólnoty lokalne muszą więc zmierzać się z wyzwaniami wykraczajacymi poza wcześniejsze schematy, wymagającymi myślenia w inny sposób niż wcześniej. Muszą rozstrzygać jedną z najbardziej kontrowersyjnych kwestii ekonomii politycznej wyrażoną w pytaniu: w jaki sposób zorganizować wykorzystywanie wspólnych zasobów, aby ograniczyć zarówno nadmierna ich eksploatację, jak i zbyt wysokie koszty, związane m.in. z koniecznością realizacji dużych inwestycji, o długim okresie zwrotu?

Punkt wyjścia niniejszego opracowania, traktowanego jedynie jako głos $\mathrm{w}$ tej ważnej dyskusji, stanowią trzy wzajemnie powiązane założenia wyprowadzone w dużej mierze z dorobku noblistki Elinor Ostrom, silnie zakotwiczonego empirycznie oraz obejmującego, zarówno udane, jak i nieudane, sposoby dysponowania wspólnymi zasobami w wielu rejonów świata:

1) Przy wyborze sposobu zarządzania zasobami wodnymi (określanego zamiennie sposobem regulacji) należy uwzględnić, że - mimo możliwości gospodarowania nimi w różnych systemach i formach własności - zarówno rozwiązania czysto rynkowe, ze względu na potencjalną zawodność rynku (market failure), jak i etatystyczne, doktrynalnie sprzeczne z obowiązującymi zasadami gospodarki rynkowej, mogą prowadzić do unicestwienia części tych zasobów i obniżenia dobrobytu społecznego.

${ }^{5}$ Dz. Urz. UE 2006 C 321E; M. Biernacki et al., Propozycje syntetycznego miernika oceniajacego działalność instytucji użyteczności publicznej, „Zarządzanie Publiczne” 2013, nr 2(22).

${ }^{6}$ Dyrektywa 2000/60/WE Parlamentu Europejskiego i Rady z 23 października 2000 r. ustanawiająca ramy wspólnotowego działania w dziedzinie polityki wodnej.

${ }^{7}$ M. Słodowa-Hełpa, Interdyscyplinarna natura paradygmatu rozwoju - uwarunkowania i propozycje usprawnienia dialogu, „Nierówności Społeczne a Wzrost Gospodarczy” 2015, nr 41(1), s. 67.

${ }^{8}$ W 2013 r., ramach serii wydawniczej Nobliści, ukazał się przekład jej pionierskiej pracy z 1990 r., doskonale wpisującej się w debatę o roli zasobów wspólnych oraz mechanizmów zarządzania nimi. Por. E. Ostrom, Dysponowanie wspólnymi zasobami, tłum. Z. Wiankowska-Ładyka, Wolters Kluwer, Warszawa 2013. 
2) Optymalne zarządzanie zasobami wodnymi wymaga zawsze regulacji opartych na zestawie warunków i zasad ich skutecznego eksploatowania ${ }^{9}$.

3) Bez nich nadal aktualne jest zagrożenie tragedią wspólnego pastwiska, ujawniona już w latach trzydziestych XIX w. przez ekonomistę Williama Lloyda ${ }^{10}$, a później szeroko analizowana przez biologa Garretta Hardina, ukazującego zbiorowe konsekwencje, do jakich może doprowadzić egoizm racjonalnie działajacych jednostek ${ }^{11}$.

Tezę o potrzebie regulacji i respektowania zasad zarządzania zasobami wodnymi potwierdza znamienna ewolucja poglądów G. Hardina, który - w dużej mierze pod wpływem dyskusji z E. Ostrom - uznał, że swój słynny esej, przywoływany przez wielu ekonomistów, powinien raczej zatytułować: Tragedia niezarzadzanego lub źle zarzadzanego dobra wspólnego (The Tragedy of the Unregulated Commons). Potwierdza ją również relatywnie optymistyczny wydźwięk badań E. Ostrom, odpierajacych nieuchronność zagrożeń tą „tragedią", pod warunkiem jednak sprawnego zarządzania ${ }^{12}$.

Ze względu na rozległość podjętej problematyki w niniejszym opracowaniu nie jest możliwe zmierzenie się z wszystkimi problemami optymalnego zarządzania zasobami wodnymi oraz z dylematami ujawniajacymi się na różnych płaszczyznach. Rozważania ograniczone będą do wybranych aspektów, ujętych z perspektywy dwóch dyscyplin należących do dziedziny nauk ekonomicznych i koncentrujących się na alokacji zasobów, czyli do ekonomii ${ }^{13}$ i nauk o zarządzaniu ${ }^{14}$. Uwzględnione zostana, choć w różnej skali, problemy o wymiarze ogólnospołecznym generujące długoterminowe skutki wykraczające poza granice przedsiębiorstw, jak i dylematy zarządcze związane z bieżącym funkcjonowaniem przedsiębiorstw wodociagowych. Wprawdzie te drugie odnoszą się do polskich realiów, to jednak ukazują ogólniejsze problemy, których nie można bagatelizować w poszukiwaniu recept na przezwyciężanie barier dostępu do zasobów wodnych związanych z naruszeniem zdolności odtworzeniowych i wyczerpaniem się tych zasobów.

9 Szerzej: M. Słodowa-Hełpa, Odkrywanie na nowo..., s. 18-20.

${ }_{10}$ W. Lloyd przyją, że pastwisko, na którym wypasana jest określona liczba zwierząt, stanowi dobro wspólne dostępne dla wszystkich pasterzy. Skoro każdy z nich dąży do maksymalizowania korzyści przez zwiększenie stada, intensyfikacja wykorzystania pastwiska może doprowadzić do hipereksploatacji, w skrajnym wypadku podważającej podstawy egzystencji użytkowników i prowadzącej do zagłady wspólnych zasobów.

11 G. Hardin, Extentions of „The Tragedy of the Commons”, „Science” 280, 1998, s. 682-683.

12 J. Ganciarowska-Ziołecka, J. Średnicka, Kapitał społeczny w ujęciu Elinor Ostrom: triumf interdyscyplinarności, „Polityka Społeczna” 2011, nr 5-6, s. 7-12.

${ }^{13}$ Według L. Robbinsa, ekonomia jest dyscyplina, której przedmiot zainteresowania stanowia „ludzkie zachowanie jako stosunek między danymi celami i ograniczonymi środkami (oznaczającymi tu zasoby) o alternatywnych zastosowaniach”. L. Robbins (ed.), The Common Sense of Political Economy, and Selected Papers on Economic Theory, by Philip Wicksteed, G. Routledge and Sons, Ltd., London 1933.

${ }^{14}$ Zdaniem R. Griffina, istota zarządzania, definiowanego najczęściej z perspektywy zasobowej, sprowadza się do takiego dobierania i koordynowania zasobów (ludzkich, finansowych, materialnych i informacyjnych), aby możliwe było osiagnięcie celów organizacji. Por. R. W. Griffin, Management, Houghton Mifflin Company, New York 1999. 
Nie oznacza to jednak, że zajęte zostanie jednoznaczne stanowisko dotyczące najbardziej zasadnych form i sposobów regulacji. Idąc za głosem E. Ostrom, do której dorobku nawiązujemy też w zasadniczej części opracowania, w pełni podzielamy jej pogląd o nadmiernej skłonności naukowców do formułowania „optymalnych" rozwiązań problemów związanych z użytkowaniem zasobów będacych wspólną własnością (common pool resources) ${ }^{15}$. Znane sa przecież przykłady zarówno udanych, jak i chybionych działań polegających na prywatyzacji, upaństwowieniu, komunalizacji, czy też zarządzania tymi zasobami $\mathrm{w}$ innej formule, np. partnerstwa publiczno-prywatnego. Wiadomo też, że silnie przez jakiś czas promowana prywatyzacja po okresie niespełnionych obietnic dotyczących dostępu, jakości i cen wody, bywa w części rejonów świata odrzucana, a nabiera przyśpieszenia trend rekomunalizacji i przypadki odzyskiwania publicznej kontroli nad uprzednio sprywatyzowanymi usługami wodno-kanalizacyjnymi ${ }^{16}$. Choć takie rozwiazania przynosza niektórym społecznościom niezaprzeczalne korzyści, zadając kłam twierdzeniom części badaczy i międzynarodowych instytucji o lepszym funkcjonowaniu sektora prywatnego, to jednak na tej podstawie nie można generalizować.

Zasadniczym celem niniejszego opracowania jest identyfikacja i ocena uwarunkowań zarządzania zasobami wodnymi oraz dylematów związanych z potrzeba przezwyciężania nadmiernej ich eksploatacji. Temu celowi podporządkowane zostały cele szczegółowe wyrażone w formie następujących pytań:

- jakie okoliczności decyduja o strategicznym charakterze zasobów wodnych?

- jakie rozwiązania regulacyjne wchodzą $\mathrm{w}$ rachubę $\mathrm{w}$ procesie zarządzania nimi?

- jakie warunki i zasady powinny być respektowane w tym procesie?

- z jakimi dylematami muszą zmierzać się przedsiębiorstwa zajmujące się redystrybucją wody?

- jakie względy decydują o multi- i interdyscyplinarnym charakterze podjętych problemów?

Na tle nakreślonych już przesłanek i założeń w kolejnej części opracowania zaprezentowane zostaną zróżnicowane bariery dostępu do zasobów wodnych, decydujące o ich strategicznym charakterze. Przedmiotem kolejnej części, będącej swego rodzaju pomostem między warstwa teoretyczną a aspektami praktycznymi, są ogólne rozwiązania regulacyjne obowiązujące w gospodarce. Następnie przedstawione zostaną warunki i zasady skutecznego zarządzania zasobami wodnymi oraz wybrane dylematy związane z funkcjonowaniem

15 E. Ostrom, Instytucje i środowisko, „Zarządzanie Publiczne” 2012, nr 2(20), s. 87.

${ }_{16} \mathrm{~W}$ ciagu ostatnich 15 lat w 37 krajach odnotowanych zostało ponad 235 przypadków ponownego przejęcia przez sektor publiczny kontroli nad usługami wodno-kanalizacyjnymi. Tylko w USA od 2000 r. miało miejsce 85 takich przypadków. W Dżakarcie pozew złożony przez mieszkańców doprowadził do wstrzymania prywatyzacji. Odzwierciedleniem takich procesów w Polsce było m.in. odkupienie od prywatnego partnera w 2014 r. przez samorząd Dąbrowy Górniczej udziałów w spółce wodociągowej. Por. S. Kishimoto, Globalne zagrożenie dla zasobów wodnych, http://zielonewiadomosci.pl [dostęp: 26.09. 2016]; A. Kobyłka, Malejace zasoby wody: globalny problem przyszłości, http://www.psz.pl/169-raporty [dostęp: 14.09.2016]; Wodociagi znów dabrowskie, https://www.dabrowa-gornicza.pl/aktualnosc-1-28287.html [dostęp: 8.09.2016]. 
przedsiębiorstw wodociagowych w Polsce. W zakończeniu znalazły się wnioski i postulaty wypływające z przeprowadzonych analiz, odnoszące się zarówno do sfery poznawczej, jak i praktycznej.

\section{STRATEGICZNY CHARAKTER ZASOBÓW WODNYCH I BARIERY DOSTĘPU DO NICH}

Strategiczny charakter zasobów wodnych wynika z ich znaczenia egzystencjalnego, gospodarczego i cywilizacyjnego moderowanego skalą barier dostępu do nich. Te bariery mają różny charakter, zależny w dużej mierze od poziomu rozwoju cywilizacyjnego, jak i lokalizacji geograficznej ${ }^{17}$. Zwiąane sa z nierównomiernością rozłożenia zasobów wodnych w skali międzynarodowej i krajowej, z różną ich dostępnością i elastycznością popytu, z dużą podatnością na występowanie tzw. efektów zewnętrznych, a także ze sposobem wprowadzenia zmian, rozwiązaniami o charakterze korupcyjnym, stanowiącymi jedna z przyczyn konfliktów o charakterze społecznym, ekonomicznym, politycznym, a nawet militarnym ${ }^{18}$.

Coraz częściej za zagrożenie dostępu do zasobów wodnych uznaje się też tryb rozwiązywania sporów między inwestorami a instytucjami publicznymi, będących odpowiedzią na katastrofalne skutki niektórych prywatyzacji i stosowanie tzw. mechanizmu ISDS, czyli ochrony praw inwestorów ${ }^{19}$.

O skali problemu związanego z postępującymi utrudnieniami lub wręcz brakiem dostępu do wody w skali globalnej świadczy najlepiej rosnący odsetek osób borykających się z tymi ograniczeniami. Obrazują to przytoczone niżej fakty:

1) Ze względu na dynamiczny wzrost zaludnienia, a przy tym znacznie większe niż dawniej zużycie wody, na każdą statystyczną osobę przypada jej coraz mniej. Podczas gdy w XX w. liczba ludności świata wzrosła trzykrotnie, ilość zużywanej słodkiej wody aż sześciokrotnie. Najwyższe tempo przyrostu naturalnego ma miejsce właśnie tam, gdzie wody brakuje najbardziej ${ }^{20}$.

2) W 1960 r. z problemami dostępu do wody zmagało się 19\% ludności świata, w 1980 - 38\%, a w 2005 - już aż $50 \%{ }^{21}$.

3) Zanieczyszczenie źródeł wody pitnej, widoczne szczególnie w krajach najbiedniejszych i objętych konfliktami, jest równie niebezpieczne jak walki zbrojne, ponieważ z danych ONZ i WHO wynika, że każdego dnia z powodu chorób przenoszonych przez wodę nieodpowiedniej jakości oraz niewłaściwej

17 D. W. Bromley, Property regimes and pricing regimes in water resources management, w: The Political Economy of Water Pricing Reforms, Oxford-New York, s. 29-48.

18 Szerzej: P. Gruszczyński, op. cit.; P. Kowalczak, Konflity o wodę, Wyd. Kurpisz, Poznań 2007; A. Thier, Korupcja w gospodarce wodnej, „Aura. Ochrona Środowiska” 2015, nr 3.

19 A. Germanos, Woda w publicznych rękach, http://zielonewiadomosci.pl [dostęp: 20.09.2016].

${ }^{20}$ J. Cipiur, Paradoks wartości czystej wody, https://www.obserwatorfinansowy.pl [dostęp: 29.09.2016].

${ }^{21}$ D. Owen, The Sound of Thirst. Why Urban Water for all is Essential, Achievable and Affordable, Parthian, Cardigan, 2012. 
infrastruktury sanitarnej umiera ok. 4000 dzieci, czyli więcej niż z powodu AIDS, ospy czy malarii ${ }^{22}$.

4) Brak dostępu do wody jest problemem nie tylko krajów najbiedniejszych. Według Programu Oceny Zasobów Wodnych na Świecie (World Water Assessment Programme) w Unii Europejskiej ponad milion osób nadal nie ma dostępu do czystej wody pitnej, a niemal $2 \%$ ludności nie ma dostępu do infrastruktury sanitarnej. Zły stan rurociagów powoduje wyciek od $10 \%$ do $40 \%$ płynacej nimi wody ${ }^{23}$.

5) Wbrew pozorom, problem niedoboru wody dotyczy także Polski, która ma jedne z najmniejszych zasobów słodkiej wody w Europie; rocznie na jednego mieszkańca przypada jej 1,5 tys. $\mathrm{m}^{3}$, czyli trzykrotnie mniej niż średnio na kontynencie ${ }^{24}$.

\section{ISTOTA I SPOSOBY REGULACJI W GOSPODARCE}

W zależności od tego, z jakim rodzajem zasobów mamy do czynienia, różna może być przydatność możliwych sposobów regulacji. Zawsze jednak doniosłość optymalnej alokacji zasobów wynika z ich zastosowań oraz z faktu, że poprawnie alokowane przyczyniają się do możliwie najwyższego przyrostu dobrobytu ${ }^{25}$.

Najogólniej rzecz biorąc, w literaturze ekonomicznej zazwyczaj wyróżnia się dwa skrajne sposoby regulacji gospodarki jako całości lub poszczególnych jej składników, mogących stanowić gospodarki poszczególnych regionów, czy też elementy wydzielone ze względu na inne kryterium. Często stosowanym kryterium podziału gospodarki na części z myślą o uwzględnieniu w sposobie ich regulacji specyficznych cech danego obszaru gospodarowania są branże albo sektory.

$\mathrm{Na}$ wysokim poziomie abstrakcji regulacja systemu może być ujmowana jako związane z rozwojem porządkowanie procesów gospodarczych, u podstaw których, w dość powszechnym przekonaniu, leży wzrost społecznego podziału pracy, pociagający za sobą dwa wzajemnie powiązane skutki: ciąłe różnicowanie i komplikowanie się struktur gospodarczych oraz rosnącą specjalizację funkcji i upraszczanie poszczególnych czynności, tak by złożoność zadań nie przekraczała intelektualnych możliwości wykonujacych je jednostek i grup ${ }^{26}$. W krótkim okresie te zjawiska prowadzą zazwyczaj do wzrostu dezintegra-

${ }^{22}$ Woda - wspólne dobro, Debata w Podkomisji Praw Człowieka, Parlament Europejski, 21 czerwca 2016 [dostęp: 14.09.2016].

${ }^{23}$ Ibidem.

${ }^{24}$ Mniejsze zasoby maja jedynie Malta, Cypr i Czechy. Por. J. Cipiur, op. cit.

${ }^{25} \mathrm{~W}$ tej części artykułu wykorzystano fragmenty zaczerpnięte z: M. Gorynia, Teoria i polityka regulacji mezosystemów gospodarczych a transformacja post-socjalistycznej gospodarki polskiej, Wyd. AE, Poznań 1995.

${ }^{26}$ S. N. Eisenstadt, Social change, differentiation and evolution, w: N. J. Demerath, R. E. Peterson (eds.), System, Change and Conflict. A Reader in Contemporary Sociological Theory and the Debate over Functionalism, Free Press, New York 1967. 
cji gospodarczej. O tym, czy będzie ona również ich długofalowym efektem, decyduje fakt, czy różnicowaniu i specjalizacji towarzyszy rozwój mechanizmów regulacji procesów gospodarczych. Rezultatem regulacji, rozumianej jako porządkowanie, jest stan negentropii strukturalnej, którego nasilenie określa odchylenie od najbardziej prawdopodobnego, chaotycznego rozmieszczenia elementów wchodzących w skład zorganizowanej całości. Istotną cechę systemu zorganizowanego, a takim jest system gospodarczy, stanowi stopień sprawności w wykonywaniu przezeń odpowiednich funkcji. Dlatego ocena organizacji systemu, oprócz stopnia uporządkowania elementów, powinna zawierać także rodzaj tego uporządkowania, jego adekwatność do wykonywania funkcji i wreszcie osiagnięty w wyniku organizacji efekt przystosowania się (funkcjonalności) ${ }^{27}$.

Odwrotnością porządku wprowadzanego przez regulację jest chaos, pojęcie potocznie postrzegane pejoratywnie, lecz w wielu dyscyplinach używane bez zabarwienia wartościujacego, jako osobliwy stan, w którym zanika jeden porządek i rodzi się drugi ${ }^{28}$. W tym znaczeniu w długiej perspektywie chaos jest czymś twórczym, umożliwiającym przejście do nowego porządku ${ }^{29}$. W krótkiej - oznacza jednak destrukcję, a więc cenę płaconą przez przyrodę i człowieka za ewolucję struktur i systemów.

W wypadku systemów gospodarczych, których działanie ma charakter celowy, proces organizowania jest jednoznaczny z porządkowaniem $\mathrm{w}$ dwóch płaszczyznach: po pierwsze, w płaszczyźnie stopnia uporządkowania, po drugie, w płaszczyźnie jakości uporządkowania. Właśnie dla określenia tego procesu stosowane jest pojęcie „regulacji”. Jeżeli system nie jest w stanie utrzymać pewnego minimum regulacji, grozi mu stopniowy rozpad (entropia).

$\mathrm{Z}$ pewnym uproszczeniem można przyjąć, że jeśli celem regulacji jest uporządkowanie systemu (osiagnięcie, utrzymanie lub pogłębienie stanu negentropii strukturalnej) oraz jeśli jego sprawność w wykonywaniu odpowiednich funkcji zależy od stopnia i sposobu uporządkowania, to sposób (mechanizm) regulacji, rozumianej w tym miejscu możliwie szeroko, wpływa na stopień sprawności systemu gospodarczego. Najczęściej przyjmuje się wielowymiarowe kryterium tej sprawności, obejmujące np.: utrzymanie równowagi gospodarczej, koszty funkcjonowania systemu, wykorzystanie zdolności produkcyjnych i przepływów informacji $\mathrm{w}$ hierarchii systemu gospodarczego ${ }^{30}$. Szeroką listę takich kryteriów, zajmującą aż pięć stron druku, przytacza János Kornai ${ }^{31}$.

Konkludując, należy podkreślić, że regulacja, będąca terminem występujacym w różnych dyscyplinach naukowych, nie ma jednoznacznej definicji, akceptowanej przez przedstawicieli nauk przyrodniczych, technicznych czy spo-

${ }^{27}$ A. A. Malinowski, Problemy ogólnej teorii systemów i ich znaczenie w biologii, w: S. May (red.), Problemy metodologii badań systemowych, Wyd. Naukowo-Techniczne, Warszawa 1973.

${ }^{28}$ Z. Hockuba, Gospodarka chaosu. Transformacja a regulacja ekonomiczna, „Ekonomista” 1993, nr 4.

${ }^{29}$ I. Prigogine, I. Stengert, $Z$ chaosu ku porzadkowi, PWN, Warszawa 1990.

${ }^{30}$ A. B. Bieć, Organizacja i sprawność systemu gospodarczego. Elementy teorii, PWN, Warszawa 1988 , s. 5 .

${ }^{31}$ J. Kornai, Anti-Equilibrium. Teoria systemów gospodarczych. Kierunki badań, PWN, Warszawa 1973 , s. 282-286. 
łecznych, w tym ekonomicznych. W tradycji nauk ekonomicznych, a także części innych dyscyplin, spotykane są liczne jej znaczenia, niekoniecznie zbieżne z przedstawionym, szerokim, abstrakcyjnym rozumieniem tego terminu. W rozpatrywanym tutaj sensie regulacja ma prowadzić do uzgodnienia oraz skoordynowania rozproszonych działań i interesów, a jej końcowym efektem powinna być wyższa sprawność (efektywność) systemu.

\section{ZASADY ZARZĄDZANIA ZASOBAMI WODNYMI}

Rozważania dotyczące zarządzania zasobami wodnymi można prowadzić na kilku poziomach abstrakcji, w uproszczeniu dających się zredukować do dwóch:

- ogólne, kompleksowe, całościowe zarządzanie gospodarką w skali jakiegoś państwa czy w skali międzynarodowej, a nawet globalnej,

- szczegółowe instrumenty wykorzystywane przy regulacji zachowań podmiotów wchodzących w skład systemu gospodarki wodnej.

Na poziomie całego systemu Marek Wąsowicz sformułował kilka ogólnych zasad, którym powinno być podporządkowane zarządzanie zasobami wodnymi. Są wśród nich ${ }^{32}$ :

- gospodarowanie tym zasobami w układzie wyodrębnionych zlewni hydrograficznych;

- kompleksowe podejście i szerokie rozumienie ochrony, obejmujące także wody powierzchniowe ('śródlądowe i morskie) i wody podziemne;

- jednoczesne uwzględnienie aspektów jakościowych i ilościowych;

- osiaganie przyjętych celów proekologicznych;

- uspołecznienie procesu zarządzania z poszanowaniem zasad demokracji partycypacyjnej;

- szerokie wykorzystanie mechanizmów rynkowych;

- pozostawienie niektórych strategicznych decyzji w gestii władz centralnych;

- utrzymanie niezbędnej kontroli oraz nadzoru w zakresie przestrzegania obowiązującego prawa przez administrację państwową i ponadpaństwowa.

Dzieli on system zarządzania gospodarką wodną na pięć następujących podsystemów, realizujących jego funkcje: organizowanie, planowanie, zasilanie, motywowanie i kontrola ${ }^{33}$.

Na poziomie szczegółowym wyróżnia się trzy typy instytucji, rozumianych jako zestawy formalnych i nieformalnych reguł kierujących zachowaniem użytkowników wspólnych zasobów wodnych (podmiotów pozyskujących/wydobywajaccych wodę) ${ }^{34}$ :

\footnotetext{
${ }^{32}$ M. Wasowicz, Podstawy ekonomiki gospodarki wodnej, Oficyna Wydawnicza Politechniki Warszawskiej, Warszawa 2000, s. 82-83.

${ }^{33}$ Ibidem, s. 83-97.

${ }^{34}$ K. Madani, A. Dinar, Exogenous regulatory institutions for sustainable common pool resource management: application to groundwater, „Water Resources and Economics” 2013, nr 2-3, s. $57-76$.
} 
- instytucje zarządzania niekooperacyjnego (non-cooperative management institutions), których wady, nazywane tragedią wspólnego pastwiska, ukazane najszerzej przez W. Lloyda i G. Hardina, moga jednak być niwelowane przez uczenie się na podstawie doświadczenia (heuristic behavior);

- instytucje zarządzania kooperacyjnego (cooperative management institutions), szeroko analizowane przez E. Ostrom, gdzie obowiązuja reguły racjonalności grupowej, a współpraca prowadzi do eliminacji lub minimalizacji efektów zewnętrznych i do zwiększenia w długim okresie korzyści wszystkich użytkowników;

- zewnętrzne instytucje regulacyjne przeciwdziałające nadmiernej eksploatacji oraz kongestii, skierowane głównie na użytkowników mających skłonności do przestrzegania wyłącznie kryterium indywidualnej racjonalności. Takie sytuacje, wymagające istnienia zewnętrznych instytucji regulacyjnych, sa stosunkowo liczne.

W zależności od uwarunkowań sytuacyjnych te instytucje mogą mieć różny charakter i przyjmować cztery postaci decydujące o efektywności uzyskiwania zamierzonych rezultatów. Są to regulacje:

1) bazujace na kwotach eksploatacji (quota-based regulatory institution) każdy użytkownik ma przypisane maksymalne wielkości (kwoty) pozyskania zasobu;

2) oparte na stanie eksploatowanego systemu (status-based regulation) - kwoty dozwolonej eksploatacji zasobu definiowane elastycznie dla różnych okresów i zależne od stanu systemu w tych okresach;

3) wykorzystujące rozwiązanie o charakterze podatkowym (tax-based regulation) - wprowadzane po to, by ograniczyć eksploatację (uczynić ją droższa) i mające różne postaci - podatek zawarty w cenie energii elektrycznej, podatek wydobywczy;

4) uwzględniające koncepcję bankructwa (bankruptcy-based regulation) i traktujące zasób, jak bankrutująca jednostkę - kwoty eksploatacji pomniejszane są o określone wartości kalkulowane $\mathrm{z}$ wykorzystaniem różnych metod bankructwa.

Na podstawie przeprowadzonych symulacji numerycznych Kaveh Madani i Ariel Dinar wykazali, że z punktu widzenia trzech kryteriów (dobrobyt społeczny, sprawiedliwość oraz odporność regulacji) najlepszymi rozwiązaniami służącymi racjonalizacji eksploatacji zasobów wspólnych są koncepcje regulacji bazujące na określeniu wielkości wydobycia i maksymalnych kwot ${ }^{35}$. Kwotowanie oraz inne systemy regulacji dostępu do źródeł sa przedmiotem licznych prac podejmujących kwestie regulacji systemu taryfowego związanego z dostępem.

Badania przeprowadzone przez A. Dinara wskazują na duże zróżnicowanie systemów regulacji taryfowej na świecie w obszarach rolnictwa, przemysłu i zużycia dla celów gospodarstw domowych. Autor wprawdzie nie przedstawia jednego preferowanego systemu regulacji, zwraca jednak uwagę na konieczność uwzględnienia przy reformowaniu systemu taryfowego czynników spo-

35 Ibidem, s. 57-65. 
łecznych i instytucjonalnych, a także uwarunkowań zewnętrznych w postaci ograniczeń w dostępie do źródeł wody ${ }^{36}$.

$\mathrm{Z}$ kolei analiza zmian systemu regulacji w Indiach, przeprowadzona przez Daniela W. Bromleya, pozwoliła na sformułowanie trzech tez dotyczacych wprawdzie warunków skuteczności zmian systemu regulacji opłat za wodę do celów rolniczych, ale mogących znaleźć zastosowanie również na innych, nierolniczych obszarach regulacji ${ }^{37}$. Pierwsza teza dotyczy konieczności stworzenia organizacji wiążącej wszystkie podmioty w ramach zarządzania i utrzymania systemu wodnego. Druga teza odnosi się do systemu taryfowego i systemu zarządzania woda, rozumianego jako część struktury własności, w którą rolnicy są włączeni. Trzecia teza wiąże się z koniecznością postrzegania systemu taryfowego jako elementu zasad, w których rolnicy nakłaniani są do uczestniczenia w kontrybucji na rzecz dobra wspólnego, poprawy zarządzania woda, które przynosi korzyści każdemu z nich.

Ekstrapolacja tych tez na cały system taryfowy wydaje się obecnie uzasadniona. Równocześnie, równolegle z propozycjami reform systemów taryfowych, ważny jest silny nacisk na uwzględnienie w szczególny sposób sytuacji osób będących w trudnej sytuacji materialnej.

Odrębnym problemem związanym z dostępem do wody jest powiązanie przez Piotra Kowalczaka procesu urbanizacji z „nieprzenoszalnością zasobów wodnych. Zależności te zmieniają w dynamiczny sposób paradygmat zarządzania zasobami wodnymi dotyczący równego obciążania za dostęp do tego samego dobra ${ }^{38}$.

Warto jednak wrócić do kwestii jeszcze bardziej ogólnych, wręcz o charakterze filozoficznym, leżących u podstaw takiego rozwiązania w zakresie zarządzania zasobami wodnymi, by dało się uniknąć wspomnianej tragedii, będącej wprawdzie przenośnym, lecz bardzo wymownym opisem niebezpieczeństw związanych z gospodarowaniem wszelkimi rzadkimi zasobami ${ }^{39}$.

Po pierwsze, można mieć wątpliwości co do adekwatności neoklasycznej analizy ekonomicznej odnoszącej się do problemów eksploatacji i wyczerpywania się zasobów naturalnych, w tym także wody. Zgodnie z logiką tej analizy rosnaca rzadkość występowania zasobu powinna prowadzić do wzrostu jego cen, co może wywoływać efekt substytucji. Tym samym problem ograniczoności i wyczerpywania się zasobów zostaje sprowadzony do kwestii techniczno-optymalizacyjnych. Dlatego w odniesieniu do kwestii ekologicznych postuluje się uwzględnianie nie tylko ocen o charakterze ekonomicznym, ale także politycznym.

Po drugie, w ujęciu keynesowskim w ochronie zasobów przyrody decydujące znaczenie mają, ,zdeterminowane politycznie oceny dotyczące potrzeby zachowania środowiska dla przyszłych pokoleń” ${ }^{40}$. Chodzi więc o podkreślenie roli

36 W. A. Dinar, The Political Economy of Water Pricing Reform, OUP, New York 2000.

37 D. W. Bromley, Property Regimes and Pricing Regimes in Water Resources Management, 2000.

38 P. Kowalczak, Wodne dylematy urbanizacji, Wyd. PTPN, Poznań 2011.

39 B. Fiedor (red.), Podstawy ekonomii środowiska i zasobów naturalnych, C. H. Beck, Warszawa 2002, s. 121.

40 Ibidem, s. 121. 
kryterium międzygeneracyjnej sprawiedliwości ekologicznej, a nie samej efektywności mikroekonomicznej. W odniesieniu do zasobów naturalnych rynek nie jest wystarczajacym mechanizmem regulacyjnym. Nie wszystkie efekty środowiskowe (zarówno koszty, jak i korzyści) daje się ująć w kategoriach czysto pieniężnych, wręcz przeciwnie - istnieje szerokie pole dla ocen politycznych.

Po trzecie, w sporze o wyższość jednego z dwóch paradygmatów konieczne jest poszukiwanie kompromisu ${ }^{41}$, czyli ekologicznego paradygmatu ekonomii i tworzenie ekologicznej metanauki, który podkreśla, że ekologiczne aspekty rozwoju gospodarczego są absolutnie nadrzędne i nawołuje do odejścia od „gospodarki kowbojskiej” w kierunku gospodarki „Ziemi jako statku kosmicznego" oraz paradygmatu ekonomizacji środowiska. Drugi zakłada szerokie wykorzystanie w analizie optymalizacyjnej narzędzi ekonomicznych i postuluje daleko idaccą ekonomizację wykorzystania środowiska. Jednocześnie nie dostrzega potrzeby tworzenia ekologicznej metanauki, stawiając na autonomię i współpracę poszczególnych dyscyplin zajmujących się eksploatacją zasobów naturalnych.

Po czwarte, postulat zrównoważonego podejścia odnosi się także do sporu dotyczącego możliwości ujęcia we współczesnej nauce, w szczególności w ekonomii i ekologii, relacji człowiek-przyroda. Z jednej strony podnosi się potrzebę zmiany stanowiska antropocentrycznego, bez konieczności jego radykalnego odrzucenia. Z drugiej strony zakłada się potrzebę odrzucenia antropocentryzmu na rzecz przyrodocentryzmu (biocentryzmu). Proponowane są różne sposoby rozwiązywania problemów ekologicznych, takie jak: ekofaszyzm, ekoanarchizm, bioregionalizm, ekofeminizm czy głęboka ekologia. W trzecim podejściu, określanym jako ekskluzjonizm, przyjmuje się stanowisko bezwzględnej wyższości człowieka wobec środowiska przyrodniczego, a jednocześnie jego stałej kontroli i panowania nad środowiskiem. Współczesne nurty filozoficzne i etyczne eksponuja kompromisowe rozwiązania, znajdujace odzwierciedlenie choćby w koncepcjach nowej etyki antropocentrycznej oraz etyki ekologicznej.

W licznych nurtach ekonomii (np. w nowej ekonomii instytucjonalnej, ekonomii branży oraz ekonomii ewolucyjnej) ukazywana jest różnorodność powiązań pomiędzy podmiotami gospodarczymi, wychodzaca daleko poza zależności ujmowane przez czystą teorię cen. Podkreśla się, że - oprócz tradycyjnie analizowanych stosunków konkurencyjnych oraz regulacyjnej roli państwa - ważna rolę odgrywają powiązania kooperacyjne pomiędzy podmiotami gospodarczymi i przejście od koncepcji konkurowania opartej na rywalizacji do koncepcji opartej na współdziałaniu. Kooperacja, postrzegana wcześniej jako czynnik redukujący konkurencję, coraz częściej ujmowana jest w powiązaniu z nią. W ślad za powstaniem różnych form jednoczesnej współpracy oraz konkurowania pojawiają się nowe, niekonwencjonalne kategorie określajace takie „mariaże”, jak: koopetycja i kooperencja ${ }^{42}$, związane z ewoluowaniem od prostych form uzyskiwania przewag konkurencyjnych do coraz bardziej skomplikowanych, trudnych do zawłaszczenia i naśladowania, oznaczajacego

${ }^{41}$ K. E. Boulding, Economics as a Science, McGraw-Hill, New York 1970.

42 J. Cygler, Kooperencja przedsiębiorstw. Czynniki sektorowe $i$ korporacyjne, Wyd. SGH, Warszawa 2009. 
symbiozę konkurencji i kooperacji ${ }^{43}$ zmieniające relacje wygrany-przegrany na wygrany-wygrany ${ }^{44}$. Bywa nawet proponowane zastępowanie terminu competition pojęciem coopetition.

Koopetycja, wyjaśniana przez teorię gier oraz przez teorię zasobową firmy, występuje wszędzie tam, gdzie konkurencja i kooperacja realizowane sa jednocześnie. Jest zatem strategią ukierunkowaną na wykorzystanie synergii, będacej efektem działania przedsiębiorstw w sieci oraz ich odpowiedniej konfiguracji względem siebie i innych uczestników sektorów, uwidaczniająca się najlepiej w strukturach łańcuchów dostaw. W ramach tych metastruktur przedsiębiorstwa współpracuja ze soba, działając na większych, bardziej konkurencyjnych i wartościowych rynkach, ale też rywalizują w celu otrzymania największych korzyści. Współpraca pozwala im na wzmocnienie siły przetargowej, lepsze wykorzystanie zasobów oraz organizacyjne uczenie się. O dynamice interakcji decyduje wspólne formułowanie celów współdziałania i niezależne celów konkurowania ${ }^{45}$. Źródłem przewagi konkurencyjnej może być posiadanie unikalnych zasobów materialnych i niematerialnych, w szczególności zasobów w postaci zdolności i kompetencji.

W warunkach globalizacji i internacjonalizacji, wymuszajacych osiaganie przewag konkurencyjnych na rynkach międzynarodowych, dobrym przykładem firm kooperujących i konkurujących ze soba, połączonych wspólnym celem i przyczyniających się do realizacji zadań, dla których zostały powołane, sa klastry ${ }^{46}$.

\section{DYLEMATY ZWIAZZANE Z FUNKCJONOWANIEM PRZEDSIĘBIORSTW WODOCIĄGOWYCH W POLSCE}

Niezwykle ważne są dylematy związane z działalnością przedsiębiorstw wodociagowych funkcjonujących w Polsce na podstawie wielu aktów prawnych $^{47}$ oraz uregulowań wynikających z członkostwa w Unii Europejskiej i z transpozycji prawa wspólnotowego na polski grunt legislacyjny. O charakterze tych dylematów decyduje $\mathrm{w}$ dużej mierze fakt, że zdecydowana

${ }^{43}$ M. Aluchna et al., Kooperencja przedsiębiorstw w dobie globalizacji. Wyzwania strategiczne, uwarunkowania prawne, Wolters Kluwer, Warszawa 2013.

${ }^{44} \mathrm{Nie}$ ma potrzeby szerszego dyskursu definicyjnego, zwłaszcza gdy w literaturze prezentowane są różne interpretacje obu pojęć, a nawet sugestie, że są one synonimami i mogą być stosowane zamiennie.

${ }^{45}$ M. Słodowa-Hełpa, Rozwój zintegrowany..., s. 73; R. Strzelecka, Perspektywa konkurencji, wspótpracy $i$ koopetycji $w$ sektorze firm deweloperskich $w$ Polsce, „Zarządzanie i Finanse” 2012, nr $1 / 3$.

${ }^{46}$ M. Gorynia, B. Jankowska, Koncepcja klasterów jako sposób regulacji zachowań podmiotów gospodarczych, „Ekonomista” 2007, nr 3; M. Słodowa-Hełpa, Rozwój zintegrowany..., s. 73.

${ }^{47}$ Między innymi ustawy: z 7 czerwca $2001 \mathrm{r}$. o zbiorowym zaopatrzeniu w wodę i zbiorowym odprowadzaniu ścieków; z 18 lipca 2001 r. - Prawo wodne; z 17 września 2015 r. o samorządzie gminnym oraz o przedsiębiorstwach działających w formie spółek kapitałowych; z 15 września 2000 r. - Kodeks spółek handlowych. 
większość przedsiębiorstw powstała $\mathrm{w}$ procesie komunalizacji oraz przekształceń sektora państwowego i została w związku z tym wyposażona w majątek wytworzony przez ten sektor lub uposażona przez gminy na drodze wniesienia do spółek skomunalizowanego majątku państwowych przedsiębiorstw wodociagowych. Kwestia ta jest o tyle istotna, że rodzi konstatację co do nieodpłatnego przejęcia przez gminy praw do takich przedsiębiorstw. Skoro bowiem przed okresem zmian ustrojowych nakłady inwestycyjne były finansowane przez skarb państwa, czyli w potocznym pojęciu przez ogół obywateli, to rodzą się wątpliwości co do potencjalnego zbywania przedsiębiorstw wodociagowych, zwłaszcza w kontekście wynikających z ustawy o samorządzie gminnym obowiązków gminy w zakresie realizacji zadań na tym polu. Z drugiej strony należy jednak przyjąć, że gminom słusznie należało się posiadanie tych przedsiębiorstw, ponieważ przed okresem PRL analizowane podmioty były własnością gmin, które ze względu na zmiany ustrojowe zostały pozbawione tej własności. Kwestia ta wzmacniana jest dodatkowo przez zakres obciążeń społeczeństwa związanych z opłatami za dostarczanie wody i odbiór ścieków. Należy jednak założyć, że gmina, upłynniając swoje aktywa w postaci przedsiębiorstwa wodociagowego, może realizować inne zadania własne, których ze względu na ograniczenia wydatków obecnie realizować nie może.

Podjęte tutaj rozważania lokuja się głównie w obszarze dylematów prawnych i etycznych związanych nie tylko z ograniczeniami zasobów naturalnych, ale i innych dóbr publicznych, m.in. dochodów wspólnoty lokalnej, jaką jest gmina.

Problemy etyczne związane z funkcjonowaniem przedsiębiorstw w obszarze monopolu naturalnego regulowanego lokalnie nie zostały dotychczas podjęte w literaturze w takiej skali, jak to się dzieje w odniesieniu do innych grup interesariuszy. Z tej pespektywy sformułowane zostały trzy dylematy ujęte w postaci pytań i rozpisane niżej na pytania szczegółowe:

- Czy każdy właściciel ma pełne prawo do dysponowania pożytkami płynacymi z faktu własności przedsiębiorstwa wodociagowego?

- Czy zapewnienie dostępu do usług wodociagowych powinno być realizowane kosztem dotychczasowych klientów?

- Czy w procesie kreowania taryf za priorytet powinna być uznawana ochrona zasobów naturalnych czy wysokość rachunków za usługi wodociagowe?

Wprawdzie otwarte pozostaje pytanie co do czerpania przez gminy pożytków wynikających z bycia właścicielem przedsiębiorstwa wodociąowego, jednakże etyczny wymiar tego pytania, nieznajdujący odpowiedzi na gruncie nauk o zarządzaniu, jest związany z trzema wymienionymi niżej aspektami kształtowania polityki właścicielskiej gmin w odniesieniu do przedsiębiorstw wodociagowych.

1. Skoro gminę tworza mieszkańcy, reprezentowani przez władze, a czerpanie pożytków z przedsiębiorstwa wodociąowego oznacza podniesienie ich obciążeń, to czy podejmując decyzję o czerpaniu takich pożytków, władze gminy powinny oprzeć się na woli mieszkańców, czy raczej podchodzić do tego problemu z punktu widzenia zarządczego? 
2. Jeśli czerpanie pożytków przez gminę $\mathrm{w}$ formie dywidendy prowadzi równocześnie do wypływu środków poza gminę w postaci podatku dochodowego od osób prawnych, to czy etyczne jest stanowienie takich obciążeń wobec społeczności lokalnej w warunkach, gdy dostarczanie wody jest zadaniem własnym gminy?

3. Czy i w jaki sposób gminy powinny kształtować strukturę właścicielską oraz kreować zasady funkcjonowania przedsiębiorstwa wodociagowego?

Wymienione pytania pozostaja otwarte, zwłaszcza przy trudnościach ze znalezieniem wskaźników pomiaru prawa gmin do dysponowania majątkiem. Ponadto choć odpowiedzialność gmin za funkcjonowanie usług wodociagowych i kanalizacyjnych jest ustanowiona ustawowo, to jednak akty prawne nie doprecyzowały, co ona oznacza - czy to, że niezależnie od koniecznych kosztów wszyscy mieszkańcy gminy powinni mieć zapewniony dostęp do tych usług?

Drugi spośród dylematów związany jest z zasadami finansowania nakładów. W ujęciu historycznym wszelkie nakłady na budowę i rozwój infrastruktury wodociagowej i kanalizacyjnej były ponoszone przez gminy. W wyniku ekspansji przedsiębiorstw na inne obszary niż gmina, na terenie której przedsiębiorstwo pierwotnie prowadziło swoją działalność, sytuacja ta jednak uległa zmianie. Zadecydował o tym także proces łączenia przez kilka gmin zadania własnego, jakim jest świadczenie usług wodociagowych. W dużej części gmin doszło wówczas do przeniesienia obowiązku finansowania utrzymania oraz rozwoju majątku na przedsiębiorstwo wodociagowe. Obecnie, ze względu na problemy budżetowe gmin, nakreślony dylemat ulega zdynamizowaniu i rodzą się pytania o źródła finansowania nakładów koniecznych do utrzymania, a w szczególności do rozwoju sieci wodociagowych i kanalizacyjnych. Z doświadczeń wynika, że rozbudowa sieci wodociagowej i kanalizacyjnej prowadzona w oderwaniu od możliwości sfinansowania ich budowy przez podmioty wyposażone w taką sieć skutkuje tak wysokimi taryfami za wodę i odprowadzanie ścieków, że usługi te stają się nieakceptowalne przez potencjalnych klientów. W związku z tym rodzi się problem natury etycznej dotyczący obciążania dotychczasowych klientów kosztami budowy sieci, a tym samym dostępu do wody jako dobra podstawowego. Tę sytuację dodatkowo komplikują potencjalne problemy zdrowotne części mieszkańców, wynikające ze złej jakości wody pochodzącej z ujęć lokalnych umieszczonych na terenie nieruchomości nieobjętych dostępem do sieci wodociagowej. Zasada solidaryzmu społecznego lub jego braku jest tutaj dominująca. Przy tym, w odróżnieniu od skali globalnej, na poziomie lokalnym solidaryzm społeczny jest rozumiany i związany z próbami rozwiązywania problemów cywilizacyjnych zgodnie z zasadą zrównoważonego rozwoju ${ }^{48}$. Należy dodać, że inwestycje realizowane wcześniej bezpośrednio przez gminy miały swoje źródło finansowania w budżecie, co wiąże się z faktycznym zaangażowaniem finansowym wszystkich członków społeczności lokalnej. Rozważając sformułowany tutaj problem, w przypadku odpowiedzi twierdzącej na pytanie o finansowanie rozwoju sieci przez dotychczasowych klientów, rodzi się kolejne pytanie o szybkość realizacji tego proce-

${ }^{48}$ T. Kosiek, Zrównoważony rozwój - rozwiazanie czy ideologia, „Zeszyty Naukowe. Organizacja i Zarządzanie" 2015, z. 85, s. 233-240. 
su. Z kolei przyjęcie takiego rozwiązania może generować problemy finansowe dotychczasowych najuboższych klientów. W związku z tak postawionym problemem rodzą się następujące pytania:

1. Czy dopuszczalne jest finansowanie rozwoju dostępu do usług przedsiębiorstwa wodociagowego przez dotychczasowych jego klientów?

2. Czy należy dopuszczać do różnicowania opłat za dostawę wody oraz odbiór ścieków wynikajacego z realizacji inwestycji w jednej gminie, a jeśli tak, to $\mathrm{w}$ jakim zakresie?

3. Jaką dynamikę należy założyć przy realizacji dostępu do usług wodociągowych i kanalizacyjnych?

4. Czy decyzje $\mathrm{w}$ tym zakresie powinny być podejmowane przez władze gminy, czy bezpośrednio przez jej mieszkańców?

Jak można zauważyć, takie odpowiedzi udzielane są przez przedsiębiorstwa i władze gmin, tyle jednak, że w sposób dorozumiany przez fakty dokonane. Brakuje odpowiedzi na te pytania płynacych z nauk o zarządzaniu. Przeprowadzenie poszerzonych badań społecznych w tym obszarze wydaje się zatem ze wszech miar uzasadnione. Wprawdzie moga tu znaleźć zastosowanie zasady proponowane przez ekonomię zrównoważonego rozwoju, jednak nie rozwiążą one problemów wyrażonych w postawionych wyżej pytaniach.

W obszarze zrównoważonego rozwoju, na płaszczyźnie człowiek-środowisko, sytuuje się również kolejny, trzeci dylemat, związany z polityką stanowienia taryf $\mathrm{i}$ ich wysokości. Jego determinanty związane sa jednak z wieloma sferami. Pierwszą jest zachowanie szczególnej dbałości o zasób naturalny, jakim jest woda. Jak wynika z danych Izby Gospodarczej „Wodociagi Polskie”, w ostatnich dwudziestu latach zużycie wody przez jednego mieszkańca Polski zmniejszyło się o ok. 50\%. Otwarte pozostaje jednak pytanie o granicę zużycia jednostkowego wody, odzwierciedlającą minimalną konieczną ilość wody dla celów bytowych. O ile wielkość zużycia wody w miastach europejskich wydaje się w ostatnich latach stabilna, o tyle zróżnicowanie w poziomie jej zużycia sięga blisko $50 \%{ }^{49}$. Wysoki poziom zużycia wody związany jest nie tylko z jej ewentualnym marnotrawieniem, lecz również z koniecznością odtwarzania infrastruktury w zwiększonym wymiarze ponad ten niezbędny. $Z$ drugiej jednak strony doprowadzanie do szybkiego obniżania wolumenu wody, a co za tym idzie - również ścieków, prowadzić może do problemów natury technicznej, a dalej jakościowej wody. W Polsce nie sa znane badania dotyczące wpływu różnorodnych czynników na wielkość spożycia wody. Wyniki takich badań prowadzonych w innych krajach, np. w Hiszpanii lub w innych regionach świata, nie są możliwe do przeniesienia na grunt polski zarówno ze względu na inne uwarunkowania funkcjonujacych tam przedsiębiorstw, jak i ze względu na upływ czasu od ich przeprowadzenia ${ }^{50}$.

${ }^{49}$ P. Kowalczak, Wodne dylematy..., passim.

${ }^{50}$ W. A. Dinar, The Political Economy of Water Pricing Reform, OUP, New York 2000; E. Domene, D. Sauri, Urbanisation and water consumption: influencing factors in the metropolitan region of Barcelona, „Urban Studies” 2006, nr 43. 
Inny problem pojawiajacy się przy próbie regulacji poziomu zużycia wody jest związany z uciążliwością średniego rachunku za wodę i ścieki ${ }^{51}$. W Polsce, pomimo niższego w wartościach bezwzględnych poziomu taryf w stosunku do taryf obowiązujących w przedsiębiorstwach Europy Zachodniej, ze względu na niższy poziom dochodów ludności, uciążliwość taryf jest znacznie wyższa. W związu z tym dalszy dynamiczny wzrost taryf może doprowadzić do zubożenia istotnej części społeczeństwa, a w konsekwencji do problemów ze ściaggalnością należności i co za tym idzie - ze wzrostem kosztów funkcjonowania przedsiębiorstwa. W każdym z przypadków mamy więc do czynienia z wyborem mniejszego zła. Istotne jest jednak świadome kreowanie wielkości jednostkowego zużycia wody w perspektywie wieloletniej, z uwzględnieniem lokalnych uwarunkowań technicznych w pozyskiwaniu wody. Przy tym przez uwarunkowania techniczne rozumie się wielkość zasobów wodnych pozostających w dyspozycji przedsiębiorstwa. W naszej opinii sa trzy istotne elementy, które należy brać pod uwagę w procesie długoterminowego kreowania zużycia wody metodami ekonomicznymi. Sa to: poziom dochodów klientów, wielkość zasobów wody oraz okres użytkowania istniejącej infrastruktury technicznej. Ten ostatni element powinien określać horyzont, w którym powinno się osiagnać założone wielkości zużycia wody. Dla tak przedstawionego problemu zostały postawione wyartykułowane niżej pytania zwiąane z próba jego rozwiązania, precyzujące jedynie obszar, w którym należy się poruszać.

1. Czy istnieje wystarczający poziom świadomości społecznej, który pozwala akceptować wzrost taryf zmierzajaccy do ograniczenia zużycia zasobów naturalnych?

2. Czy poziom zasobności klientów jest na tyle wysoki, że istnieje przestrzeń do wzrostu obciążeń związanych ze wzrostem taryf za dostarczanie wody i odbiór ścieków?

3. W jaki sposób kreować politykę taryfową w danym czasie i w jaki sposób ten czas określić?

Próby odpowiedzi na tak sformułowane pytania mogą stanowić podstawę dyskusji, która wprawdzie nie rozwiąże przywołanego dylematu, jednak pozwoli na zredukowanie napięć społecznych związanych z realizacją zamierzeń. Tak jak w przypadku poprzednich dylematów, obecnie trudne jest znalezienie mierników pozwalających przenieść odpowiedzi na postawione pytania ze sfery etyki do obszaru nauk o zarządzaniu. Z przedstawionych rozważań wynika jednak, że istnieją elementy zarządcze w tych obszarach, które co prawda nie dadzą odpowiedzi na postawione pytania, ale moga prowadzić do zwiększonej racjonalności przy podejmowaniu decyzji.

Problem zysku przedsiębiorstwa wodociagowego oraz jego przeznaczenia został zauważony ostatnio również przez instytucje kontrolne, w tym przez Najwyższą Izbę Kontroli ${ }^{52}$. Mimo że NIK nie sformułowała negatywnej opinii dotyczacej pobierania przez gminy dywidendy z przedsiębiorstw wodo-

${ }^{51}$ Za miarę uciążliwości przyjmuje się ostatnio udział rachunku za usługi wodociagowe i kanalizacyjne w tzw. dochodzie rozporządzalnym. Różne są górne wartości graniczne tego wskaźnika, m.in. w USA na poziomie $2,5 \%$, a w UE (w zależności od instytucji): $3-4 \%$.

${ }^{52}$ Ksztattowanie cen ustug 2016. 
ciagowych, to fakt podjęcia tego zagadnienia i propozycje dotyczące zarówno kreowania zysków przez te przedsiębiorstwa, jak i ograniczania w sposób administracyjny marży zysku świadczą o jego istotności. Równocześnie warto zauważyć, że przedsiębiorstwa wodociagowe działają częściowo na terenie innych gmin niż te będące ich właścicielami oraz często realizują przychody poza sfera regulacyjna. W takim przypadku dylemat ulega zniekształceniu i traci swój etyczny wymiar w zakresie władztwa gminy w odniesieniu jedynie do jej mieszkańców. Pozostaje jednak otwarte pytanie co do czerpania przez gminy pożytków z faktu bycia właścicielem przedsiębiorstwa wodociagowego. Etyczny wymiar tego pytania jest oparty na trzech aspektach. Przede wszystkim rodzi się pytanie, co stanowi o sukcesie zarządzania organizacją oraz jakie sa przesłanki sukcesu podmiotu sektora publicznego, jakim jest przedsiębiorstwo wodociagowe, a także jakie decyzje podejmowane przez zarządzających tymi przedsiębiorstwami wpływają na jego wartość w najbardziej ogólnym znaczeniu tego słowa.

\section{ZAKOŃCZENIE}

Przeprowadzone rozważania dają podstawę do sformułowania kilku wniosków i postulatów. Wystapienie tragedii wspólnego pastwiska jest obiektywnym i realnym zagrożeniem dla podnoszenia dobrobytu oraz dla ciagłości ekologicznej naszej cywilizacji. Z punktu widzenia zasobów wodnych, ich rzadkości, a w szczególności nieodnawialności, należy je traktować jako swego rodzaju metaforę, uniwersalny symbol problemów stojących przed naszą cywilizacja.

Okazuje się, że społeczeństwo potrafiło wypracować takie mechanizmy regulacji zachowań podmiotów, które pozwalają na ograniczenie lub wręcz wyeliminowanie konsekwencji tego zagrożenia.

Poleganie wyłącznie na działaniu mechanizmu rynkowego może być zgubne, lecz jednocześnie nie jest wskazane daleko idące odchodzenie od niego, a raczej jego wspomaganie, uzupełnianie oraz korygowanie innymi instrumentami regulacji zachowań podmiotów gospodarczych i społeczeństwa.

Przyjęte rozwiązania winny być dostosowane do warunków miejsca i czasu, przy tym nie istnieją rozwiązania najlepsze, bezwzględnie pasujace do wszystkich warunków.

Coraz bardziej ujawniający się jeden z żelaznych problemów tzw. zawodności rynku i wysoce uproszczone spory koncentrujące się na linii rynek-państwo, sprawiaja, że na nowo odkrywana jest koncepcja dobra wspólnego, wydobywana z czarnej dziury pamięci, do której została zesłana w dużej mierze właśnie przez część ekonomistów.

Euforia związana z rosnąca atrakcyjnością dobra wspólnego, nie bez powodu określana jego drugim życiem, nie powinna jednak przysłaniać ryzyka, którego przecież nie jest pozbawiona. Należy bowiem mieć świadomość niebezpieczeństw i pułapek związanych zarówno z błędnym odczytywaniem istoty takiego dobra, z jego zbyt płytkim interpretowaniem, a także z zagrożeniami, 
związanymi m.in. z równoczesną aktywnością na tym polu badaczy oraz ruchów społecznych o różnym charakterze i rodowodzie ${ }^{53}$.

Choć w skład dobra wspólnego mogą wchodzić różne zasoby materialne i niematerialne, to jednak nie można utożsamiać go tylko z zasobami, jak to niestety bywa. Paradygmat dobra wspólnego obejmuje trzy elementy tworzące zintegrowana, współzależną całość: zasoby, społeczność oraz zestaw zasad, wartości i norm ${ }^{54}$.

Przy poszukiwaniu rozwiązań współczesnych problemów potrzebne jest formułowanie pytań, m.in., na ile nawrót do koncepcji dobra wspólnego, oferującej realne formy współuczestnictwa i odpowiedzialności, może pomóc w przezwyciężaniu bolesnych skutków zagrożenia brakiem wody.

Coraz więcej jest głosów, że w poszukiwaniu odpowiedzi na sformułowane $\mathrm{w}$ tym opracowaniu pytania konieczne jest przekraczanie granic dyscyplin, które może nie tylko działać ożywczo, lecz w XXI w. jest wręcz niezbędne do zrozumienia świata. Część ekonomistów podkreśla, że paradoksalnie dyscyplina ekonomii powinna być interdyscyplinarna, że powinna uwzględniać dorobek innych nauk społecznych, równocześnie afirmując pluralizm ujęć w obrębie swojej dyscypliny, że świat potrzebuje ekonomii włączenia, zwłaszcza gdy globalizacja i zmiany technologiczne stwarzają wprawdzie ogromne szanse, ale też gigantyczne ryzyko i zalewają nas kolejne fale rewolucji konwergencyjnej wynikającej z rosnącej synergii między jej dynamicznie zmieniającymi się składowymi, m.in.: rewolucją kwantowa, cyfrowa, biomolekularną ${ }^{55}$.

Optymistyczne jest to, że wiosna w ekonomii zatacza coraz szersze kręgi, że apele o jej większe zakorzenienie w społeczeństwie i etyce nie pozostają bez reakcji. Coraz więcej ekonomistów wskazuje na potrzebę powiązań gospodarki z polityka, środowiskiem i kultura. Zamiast gospodarki niedoboru lub nadmiaru postulowana jest gospodarka umiaru i nowy pragmatyzm ${ }^{56}$. Alternatywą stają się ekonomia partycypacyjna, ekonomia złożoności, ekonomia zrównoważonego rozwoju, ekonomia dobra wspólnego, ekonomia wiedzy niedoskonałej oparta na szkole behawioralnej, czyli psychoekonomii, za której sprawa dokonuje się daleko idąca rekonstrukcja założeń koncepcji homo oeconomicus. Widać coraz większą rangę koncepcji: homo cooperativus, homo sapiens wikinomicus oraz homo sustinens bazujacej na wspólnotowych i altruistycznych wartościach, rosnącą skalę gospodarki współzależności kształtowanej pod wpływem sieciowego rozwoju technologicznego i społecznego. Towarzyszy jej rozwój bioekonomii i biogospodarki, obejmującej praktycznie wszystkie sektory i związane z nimi usługi, stanowiącej strategiczną ponadsektorowo inte-

${ }^{53}$ Szerzej: M. Słodowa-Hełpa, Odkrywanie..., passim.

${ }_{54}$ D. Bollier, The Commons. Dobro wspólne dla każdego, Spółdzielnia Socjalna FAKTORIA, Zielonka 2014; Ch. Felber, Gospodarka dobra wspólnego. Model ekonomii przyszłości, Wydawnictwo Biały Wiatr, Rzeszów 2014.

55 G. W. Kołodko, Nowy Pragmatyzm, czyli ekonomia i polityka dla przyszłości, „Ekonomista” 2014, nr 2.

${ }^{56}$ M. Bałtowski, Ewolucja ekonomii a nowy pragmatyzm Grzegorza W. Kołodki, „Ekonomista” 2015, nr 5; M. Bałtowski (red.), Ekonomia przyszłości. Wokót nowego pragmatyzmu Grzegorza W. Kołodko, PWN, Warszawa 2016; J. Pach et al., Ekonomia umiaru. Realna perspektywa? Nowy pragmatyzm Grzegorza W. Kołodko, PWN, Warszawa 2016. 
grująca formę działań wpisującą się w interdyscyplinarne podejście do zasad planowania i finansowania badań oraz przedsięwzięć gospodarczych.

Pozytywne zmiany są też widoczne $\mathrm{w}$ innych naukach społecznych oraz w sferze praktycznej. Odnotować należy m.in.: coraz większe zainteresowanie badaczy, władz publicznych i społeczeństwa ekoinnowacjami, potwierdzajace wzrost świadomości zagrożeń środowiskowych, a także wzrost społecznej odpowiedzialności biznesu oraz aktywności i skuteczności działania wielu organizacji krajowych i międzynarodowych promujących zrównoważona produkcję. Widoczne jest także coraz bardziej profesjonalne kształtowanie relacji przedsiębiorstw z otoczeniem biznesowym i społecznym, wzrost ich wiarygodności i reputacji, stającej się ważnym elementem kreowania przewagi konkurencyjnej.

W kontekście nakreślonych przesłanek oraz pytań, które powinny być przedmiotem zintensyfikowanej debaty, wyzwaniem dla teoretyków i praktyków jest znalezienie nowych struktur prawnych, form instytucjonalnych i praktyk społecznych, które pozwolą współcześnie różnym rodzajom zasobów wspólnych funkcjonować na coraz większą skalę. Potrzebne są innowacje w prawie, polityce społecznej, samorządności, kulturze i praktyce społecznej budujące światopogląd inny od dominującego w systemach bazujących na państwie i rynku.

Choć wskazuje się na rosnącą rolę wśród kreatorów rozwoju świadomych i aktywnych konsumentów (prosumentów) przywiązujących coraz większa wagę do etycznej reputacji firm, wysokiej jakości produktów i usług, oddziałujących w coraz większym stopniu na nowe oblicze rynków przyszłości, to jednak w odniesieniu do zasobów wodnych większość społeczeństwa nie zdaje sobie sprawy z doniosłości zagrożenia tragedią wspólnego pastwiska. Stąd tak ważna jest edukacja i podniesienie poziomu świadomości społecznej, będących ważnymi instrumentami oddalenia tej tragedii. Dlatego trudna do przecenienia jest $\mathrm{w}$ tej materii rola wszystkich szczebli systemu edukacyjnego, a także mediów. Kwestie rzadkości i ograniczoności zasobów naturalnych, w tym wody, powinny stać się przedmiotem większej uwagi odpowiedzialnych ugrupowań politycznych, które nie powinny kalkulować swoich działań wyłącznie w kategoriach bieżącego cyklu politycznego, ale wybiegać do przodu, tak by uwzględniać wymiar czasowy związków pomiędzy stanem środowiska naturalnego a poziomem konsumpcji materialnej - innymi słowy, chodzi o wzięcie pod uwagę międzygeneracyjnych albo intertemporalnych różnic $\mathrm{w}$ poziomie dobrobytu społecznego.

dr Pawet Chudziński

pawel.chudzinski@aquanet.pl

prof. dr hab. Marian Gorynia

Uniwersytet Ekonomiczny w Poznaniu

marian.gorynia@ue.poznan.pl

prof. dr hab. Matgorzata Stodowa-Hetpa

Uniwersytet Ekonomiczny w Poznaniu

malgorzata.slodowa-helpa@ue.poznan.pl 


\section{WATER RESOURCES MANAGEMENT \\ - A CHALLENGE NOT FOR ECONOMISTS ONLY}

Sum mary

The inspiration to focus on water resources management in the manner presented below has originated in the authors' conviction of a need for an intensified debate on the ways of solving problems relating to the principles and rules governing the allocation of water resources and their varied uses in a situation of a growing risk of a complete use or serious abuse of water resources. These deliberations are expected to lead to an improved system of water supply and delivery and a better use of water in general. The aim of this paper was to identify and assess the dilemmas arising from solutions developed in two branches of science dealing with the allocation of resources: economy and management. However, not all problems have been capable of being effectively and unambiguously solved. The analysis was conducted at different levels, starting from issues of global character, through macroeconomic issues analysed at the national level, to the examination of companies operating as water suppliers, in an attempt to combine the cognitive aspects grounded in the existing theoretical conceptions with the more practical ones. Against such a background, the barriers hindering access to water resources have been presented. This was followed by some bridging as well as theoretical and practical aspects, and the deliberations on the general regulatory solutions adopted in the economy. After that the conditions and principles ensuring effective water resources management have been presented together with selected dilemmas pertaining to the functioning of water supply companies in Poland. A presentation of the results and postulates obtained in the course of the analysis performed, applicable to the cognitive sphere as well as the practical aspects, follows the above deliberations. 